\title{
Involvement of cytokines in the pathogenesis of hypersensitivity pneumonitis: Evaluation of immunotherapeutic measures in a mouse model
}

\author{
Michel Denis, PhD, Marie Bédard, MSc, Jacques Gagnon, PhD, Yvon Cormier, MD, Michel laviolette, MD
}

\begin{abstract}
M DENis, M BÉDARd, J Gagnon, Y CORMIER, M LAviolette. Involvement of cytokines in the pathogenesis of hypersensitivity pneumonitis: Evaluation of immunotherapeutic measures in a mouse model. Can J Infect Dis 1992;3(Suppl B):111B-114B. C57BL/6 inbred strain mice were instilled intranasally with $150 \mu \mathrm{g} /$ day of the actinomycete Faeni rectivirgula three days a week as a model of farmer's lung disease. Instilled mice developed a strong alveolitis manifested by a large increase in the number of cells in the bronchoalveolar lavage (BAL) $\left(4.1 \times 10^{4}\right.$ cells in saline controls versus $5.28 \times 10^{5}$ cells in $F$ rectivirgula-instilled mice). This influx was associated with a substantial release of pro-inflammatory cytokine in the BAL; 170 $\mathrm{U} / \mathrm{mL}$ of interleukin (IL)-1 in instilled mice whereas saline instilled mice had undetectable levels of cytokines in the BAL. In addition, pulmonary fibrosis was evident in challenged mice at three weeks (twofold increase in lung hydroxyproline levels). Infusion of a rabbit antimouse tumour necrosis factor-alpha was associated with an almost complete abrogation of all markers of the disease. Also, administration of cyclosporine A ( $50 \mathrm{mg} / \mathrm{kg} /$ day) partially prevented the alveolitis $(\mathrm{P}<0.01)$ and totally prevented cytokine release and lung fibrosis in challenged mice. These findings underscore the immunological basis of hypersensitivity pneumonitis, and suggest that antagonism of inflammatory cytokines may hold promise in the treatment of this pathology.
\end{abstract}

Key Words: Cytokines, Fibrosis, Hypersensitivity pneumonitis

\section{Rôle des cytokines dans la pathogenèse de la pneumopathie immunologique: évaluation de mesures immunothérapeutiques dans un modèle de souris}

RÉSUMÉ: Des souris de lignée C57BL/6 pure ont reçu une instillation intranasale de $150 \mu \mathrm{g}$ par jour de l'actinomycète Faeni rectivirgula trois jours par semaine, pour établir un modèle de poumon du Fermier. Les souris à qui l'instillation fut administrée ont développé une grave alvéolite, caractérisée par une forte augmentation du nombre de cellules présentes dans le liquide du lavage broncho-alvéolaire (LBA) $\left(4,1 \times 10^{4}\right.$ cellules dans les témoins physiologiques contre $5,28 \times 10^{5}$ dans les spécimens recueillis chez les souris instillées au $F$ rectivirgula). Cet influx était associé à une libération substantielle de cytokines proinflammatoires dans le LBA: $170 \mathrm{U} / \mathrm{mL}$ d'interleukine- 1 chez les souris instillées au $F$ rectivirgula, alors que les souris instillées au salin physiologique présentaient des taux non décelables de cytokines au nîveau du LBA. En outre, une fibrose pulmonaire a été rapportée chez les souris instillées au F rectivirgula dès la troisième semaine (augmentation du double des taux d'hydroxyproline pulmonaire). La perfusion du facteur de nécrose tumorale a été associée à une abrogation presque complète de tous les marqueurs de la maladie. Également, l'administration de cyclosporine A (50 mg/kg/jour) a partiellement bloqué l'alvéolite $(\mathrm{P}<0,01)$ et totalement empêché la libération de cytokines et la fibrose pulmonaire chez les souris soumises à l'allergène. Ces rêsultats soulignent la base immunologique de la pneumopathie immunologique et suggèrent que l'antagonisme des cytokines inflammatoires représente un traitement potentiel de cette pathologie. 
$\mathrm{H}$ YPERSENSITIVITY PNEUMONITIS DESIGNATES A GROUP OF lung inflammatory diseases which represent the response to inhaled actinomycetes (farmer's lung) or to animal proteins (pigeon breeder's lung) (1). The disease is characterized by an intense alveolitis, composed mostly of mononuclear cells, ie, macrophages and CD8+ lymphocytes (2). Chronic exposure to the antigens may result in the formation of loosely formed granulomas and eventual fibrosis (3). Mouse models of this important pathology have been developed based on the intranasal application of actinomycete, and this animal model may yield results of crucial importance for understanding the disease (4). This model is highly representative of human disease as it is characterized by an early neutrophilic infiltrate and a later phase of alveolitis composed principally of macrophages and lymphocytes. Chronic exposure often results in collagen deposition in the lungs, with irreversible consequences.

To deepen understanding of the immune basis of hypersensitivity pneumonitis a mouse model based on intranasal instillation of Faeni rectivirgula was studied. The effect of two anticytokine treatments, namely antitumour necrosis factor-alpha (TNF $\alpha$ ) antibodies and cyclosporine A (Sandimmune; Sandoz), were evaluated.

\section{MATERIALS AND METHODS}

Mice: Pathogen-free C57BL/6 mice weighing 18 to $20 \mathrm{~g}$ were purchased from Charles River (St-Constant, Québec).

Faeni rectivirgula: A strain of $F$ rectivirgula (also known as Micropolyspora faeni or Saccharopolyspora rectivirgula) was grown in trypticase soy broth (Difco, Michigan) for six days at $52{ }^{\circ} \mathrm{C}$ on a shaking incubator. Cells were harvested by centrifugation, homogenized and lyophilized.

Antimouse tumour necrosis factor-alpha: An immunoglobulin fraction prepared by ammonium sulphate precipitation from the serum of rabbits hyperimmunized with purified murine TNF $\alpha$ was used as the anti-TNF $\alpha$ antiserum. One milligram of antiserum neutralized $6 \times 10^{6} \mathrm{U}$ of cytolytic activity of mouse TNF $\alpha$ in an L929 killing assay (5). This antiserum contained less than $0.1 \mathrm{ng}$ of endotoxin per $10 \mathrm{mg}$ of material, as seen in a Limulus amebocyte assay (Sigma, Missouri). This antiserum did not block the bioactivity of interleukin (IL)-1, IL-2, TNF $\beta$ or interferon-gamma (IFN $\gamma$ ) in specific bioassays. IL-1 activity was measured by the thymocyte coproliferation assay of Mizel and associates (6); IL-2 activity was measured via the induction of proliferation of CTLL-D cells (6); TNF $\beta$ activity was measured via the lytic activity towards L929 fibrosarcoma cells (6); and IFN was measured by its ability to protect mouse fibroblasts from vesicular stomatitis virus infection (6).

Induction of hypersensitivity pneumonitis: Animals were lightly anesthetized by diethyl ether and given 150 mg $F$ rectivirgula antigen in $50 \mathrm{~mL}$ of saline transnasally for three successive days a week. Mice were divided into four groups: group 1 received saline only: group 2 received $150 \mu \mathrm{g}$ of $F$ rectivirgula three successive days a week for three weeks, group 3 received $150 \mu \mathrm{g}$ of $F$ rectivirgula three successive days a week for three weeks and $2 \mathrm{mg}$ anti-TNF $\alpha$ intraperitoneally weekly, and group 4 received $150 \mathrm{mg}$ of $F$ rectivirgula three successive days a week for three weeks and cyclosporine A $50 \mathrm{mg} / \mathrm{kg}$ intraperitoneally every day.

Bronchoalveolar lavage cell number: Animals were killed and cells in the bronchoalveolar lavage (BAL) were isolated by repeated lavage of the airways with $5 \mathrm{~mL}$ of $0.6 \mathrm{mM}$ EDTA in phosphate buffered saline. BAL fluid was stored at $-20^{\circ} \mathrm{C}$ and cell number assessed by trypan blue counting.

Fibrosis: The total lung hydroxyproline concentration was determined using previously described methods (7). Briefly, lungs were submitted to an acid hydrolysis, the hydrolysate was neutralized, extracted with phenolchloroform-isoamyl alcohol and hydroxyproline determined by colorimetry.

Interleukin-1 analysis: IL- 1 levels were measured by a thymocyte coproliferation assay described in detail by Mizel (8). Briefly, thymocytes from $\mathrm{C} 3 \mathrm{H} / \mathrm{HeJ}$ mice were obtained and suspended at $10^{7}$ cells $/ \mathrm{mL}$ in complete RPMI 1640 with 10\% fetal calf serum and antibiotics. One hundred microlitres of cell suspension were added to each well of a 96-well microtitre plate. Test samples of IL- 1 and antiserum were added to appropriate wells and plates incubated $48 \mathrm{~h}$ at $37^{\circ} \mathrm{C}$ with $5 \%$ carbon dioxide and a final $6 \mathrm{~h}$ pulse with $1 \mu \mathrm{Ci}$ per well tritiated thymidine. Cell-associated radioactivity was measured by beta counting.

Statistical analysis: Statistical analysis of the differences between means was performed using ANOVA, combined with the Newman-Keul test for significance at $\mathrm{P}=0.05$.

\section{RESULTS}

Alveolitis blocked by anti-TNF $\alpha$ or cyclosporine A: The histopathological profile of the transnasal instillation with $F$ rectivirgula has been described in detail (9). Instillation with $F$ rectivirgula is associated with an acute and strong inflammation with an accumulation of an inflammatory infiltrate comprising macrophages, lymphocytes and neutrophils. Histological examination was suggestive of an interstitial pathology affecting mostly the small and medium airways.

Instillation of $F$ rectivirgula by the intranasal route led to a strong influx of mononuclear cells in the BAL (Table 1). At three weeks, Giemsa staining revealed that approximately $50 \%$ of the cells were macrophages and $50 \%$ lymphocytes. As shown in Table 1, infusion of anti-TNF $\alpha$ led to a total abrogation of alveolitis. Administration of cyclosporine A (50 mg/ $\mathrm{kg} /$ day) was also associated with a significant abrogation of this alveolitis. 
IL-1 release blocked by anti-TNF $\alpha$ or cyclosporine A: As the data in Table 2 suggest, hypersensitivity pneumonitis induced the release of copious amounts of IL-1 in the BAL $(170 \mathrm{U} / \mathrm{mL})$, which was nullified by antiTNF $\alpha$ or cyclosporine A treatments.

Lung fibrosis blocked by anti-TNF $\alpha$ or cyclosporine A: Collagen deposition in the lungs of different groups of mice were determined. Hypersensitivity pneumonitis provoked a substantial fibrosis in the lungs. Administration of anti-TNF $\alpha$ or cyclosporine A blocked this fibrotic reaction, with levels of hydroxyproline similar to those of saline-instilled mice. Although lung hydroxyproline is not always strictly correlated with an ongoing fibrosis, an increased level of hydroxyproline is certainly always indicative of a lung remodeling process. Control mice were also given control rabbit globulin and a challenge of actinomycete. Results showed that infusion with rabbit globulin had no effect on the inflammation induced by $F$ rectivirgula.

\section{DISCUSSION}

This report describes immunopathological features of hypersensitivity pneumonitis and their modulation by cyclosporine A and anti-TNF $\alpha$. Intranasal instillation of $F$ rectivirgula provoked a large alveolitis, IL-1 release and lung fibrosis. Previous results with mouse models of hypersensitivity pneumonitis have emphasized the strong alveolitis seen after actinomycete challenge (4). This is consistent with findings in humans where repeated challenge brings about a drastic recruitment of mononuclear cells (10). Present results are also in agreement with results on the ability of cyclosporine A partially to block cellular recruitment (4). Of considerable interest is finding that application of an anti-TNF $\alpha$ antiserum totally abrogates cellular influx. The presence of IL-1 points to an intense inflammation in the lungs of challenged mice. This is an important point inasmuch as an alveolitis is not always representative of a true inflammatory state.

TNF $\alpha$ is a pleiotropic cytokine involved in the genesis and maintenance of inflammatory reactions (11). TNF $\alpha$ activates leukocytes and induces the synthesis of adhesion molecules involved in the recruitment of leukocytes (12). Previous data have shown the crucial involvement of TNF $\alpha$ in the development of lung injuries; after exposure to silica (13), bleomycin (14) and immune complexes (15). Present results with cyclosporine A also emphasize the immunological basis of hypersensitivity pneumonitis inasmuch as the immunosuppressive agent cyclosporine $\mathrm{A}$ is thought to act by preventing lymphokine (notably $\mathrm{TNF} \alpha$ ) expression and release (16). Overall, this suggests an important role for cytokines in the inflammation of hypersensitivity pneumonitis and similar conditions, and a crucial role for TNF $\alpha$.

It is unclear how $\mathrm{TNF} \alpha$ produces the various aspects of hypersensitivity pneumonitis, including alveolitis, IL-1 release and fibrosis. The alveolitis is surely linked
TABLE 1

Bronchoalveolar lavage (BAL) cell number in hypersensitivity pneumonitis and modulation by anticytokine reagents

\begin{tabular}{lccc}
\hline Group & $\begin{array}{c}\text { Intranasal } \\
\text { instillation }\end{array}$ & Treatment & $\begin{array}{c}\text { BAL cell } \\
\text { number }\end{array}$ \\
\hline 1 & Saline & Saline & $4.1 \times 10^{4}$ \\
2 & Frectivirgula & None & $52.8 \times 10^{4}$ \\
3 & Frectivirgula & Anti-TNF $\alpha$ & $5.3 \times 10^{4}$ \\
4 & Frectivirgula & Cyclosporine A & $22.1 \times 10^{4 \dagger}$ \\
\hline
\end{tabular}

Groups 2,3 and 4 mice were given $150 \mu \mathrm{g}$ of $\mathrm{F}$ rectivirgula intranasally for three days a week for three weeks. Group 3 mice were given 2 mg of anti-TNFa antiserum weekly. Group 4 mice were given $50 \mathrm{mg} / \mathrm{kg}$ of cyclosporine A daily. " $P<0.01$ versus the other three experimental groups; ${ }^{t} P<0.01$ versus group 2 . For all groups, standard deviations were less than $15 \%(n=6)$

\section{TABLE 2}

Interleukin (IL)-1 secretion in the bronchoalveolar lavage of hypersensitivity pneumonitis and modulation by anticytokine reagents

\begin{tabular}{lccc}
\hline Group & $\begin{array}{c}\text { Intranasal } \\
\text { instillation }\end{array}$ & Treatment & IL-1 (U/mL) \\
\hline 1 & Saline & Saline & Not detectable \\
2 & Frectivirgula & None & $170^{* *}$ \\
3 & Frectivirgula & Anti-TNF $\alpha$ & 16 \\
4 & Frectivirgula & Cyclosporine A & 6 \\
\hline
\end{tabular}

Groups 2, 3 and 4 mice were given $150 \mu \mathrm{g}$ of F rectivirgula intranasally for three days a week for three weeks. Group 3 mice were given $2 \mathrm{mg}$ of anti-TNFo antiserum weekly. Group 4 mice were given $50 \mathrm{mg} / \mathrm{kg}$ of cyclosporine A daily. ${ }^{*} P<0.001$. For all groups, standard deviations were less than $20 \%(n=7)$

\section{TABLE 3}

Lung fibrosis in hypersensitivity pneumonitis and modulation by anticytokine reagents

\begin{tabular}{lccc}
\hline Group & $\begin{array}{l}\text { Intranasal } \\
\text { instillation }\end{array}$ & Treatment & $\begin{array}{c}\text { Hydroxyproline } \\
\mu \mathrm{g} / \text { lung }\end{array}$ \\
\hline 1 & Saline & Saline & $221 \pm 26$ \\
2 & Frectivirgula & None & $418 \pm 46^{* *}$ \\
3 & Frectivirgula & Anti-TNF $\alpha$ & $236 \pm 41$ \\
4 & Frectivirgula & Cyclosporine A & $208 \pm 32$ \\
\hline
\end{tabular}

Groups 2, 3 and 4 mice were given $150 \mu \mathrm{g}$ of $\mathrm{F}$ rectivirgula intranasally for three days a week for three weeks. Group 3 mice were given $2 \mathrm{mg}$ of anti-TNFa antiserum weekly. Group 4 mice were given $50 \mathrm{mg} / \mathrm{kg}$ of cyclosporine A daily. ${ }^{*} P<0.001(n=8)$

to the ability of TNF $\alpha$ to induce the expression and release of chemotactic cytokines such as IL-8 (17). TNF $\alpha$ may be involved directly in stimulating fibrosis as TNF $\alpha$ directly stimulates collagenase activity in fibroblasts (18). Alternatively, TNF $\alpha$ may contribute to the fibrosis by stimulating the release of profibrotic molecules such as platelet-derived growth factor or transforming growth factor beta (19).

The exact role played by $\mathrm{T}$ cells in the pathology of hypersensitivity pneumonitis in the mouse model is still unclear. It may be that $\mathrm{T}$ cells play a role similar to 
that ascribed to these cells in bleomycin-induced lung injury (14), where they play a detrimental role by stimulating enhanced $\mathrm{TNF} \alpha$ release from alveolar macrophages. The role played by the different cellular mediators in the development of hypersensitivity pneumonitis is still being pursued in the authors' laboratory.

ACKNOWLEDGEMENTS: We thank Francoise Maher for expert secretarial assistance. Supported in part by the Network of the Centre of Excellence, Canada (NSERC) and by the Association Pulmonaire du Québec.

\section{REFERENCES}

1. Salaggio JE. Recent advances in pathogenesis of allergic alveolitis. Clin Exp Allergy 1990;20:137-44.

2. Leatherman JW, Michael AF, Schwarty BA, Hoidal JR. Lung T cells in hypersensitivity pneumonitis. Ann Intern Med 1984;100:390-2.

3. Schuyler M, Salvaggio J. Hypersensitivity pneumonitis. Semin Respir Med 1984;5:246-54.

4. Tikkawa H, Suko M, Kobayashi N, et al. Experimental hypersensitivity pneumonitis in the mouse: Histologic and immunologic features and their modulation with cyclosporine A. J Allergy Clin Immunol 1988;81:391-400.

5. Ruff MR, Gifford GE. Purification and physico-chemical characterization of rabbit tumor necrosis factor. $J$ lmmunol 1980;125:1671-7.

6. Coligan JE, Kruisbeek AM, Margulies DH, Shevach EM, Strober W. Current Protocols in Immunology. New York: John Wiley \& Sons, 1990.

7. Huszar G, Maiocco J, Naftolin F. Monitoring of collagen and collagen fragments in chromatography of protein mixtures. Ann Biochem 1979;105:424-31.

8. Mizel S. Production and quantitation of lymphocyte activating factor (interleukin-1). In: Herscowitz HB, Holden HT, Bellanti JA, Ghaffar A, eds. Manual of
Macrophage Methodology. New York: Marcel Dekker, 1981:329-36.

9. Denis M, Cormier Y, Laviolette M. Tumor necrosis factor plays a key role in the development of mouse hypersensitivity pneumonitis. Am J Respir Cell Mol Biol 1991:5:477-84.

10. Roberts RC, Moore VL. Immunopathogenesis of hypersensitivity pneumonitis. J Allergy Clin Immunol 1977;60:27-33.

11. Sherry B, Cerami A. Cachectin/tumor necrosis factor exerts endocrine, paracrine and autocrine control of inflammatory responses. J Cell Biol 1988; 107:1269-77.

12. Le J, Vilcek J. Biology of disease. Tumor necrosis factor and interleukin-1; cytokines with multiple overlapping activities. Lab Invest 1987;56:234-41.

13. Piguet PF, Collart MA, Grau GE, Sappino AP, Vassali P. Requirement of tumor necrosis factor for development of silica-induced pulmonary fibrosis. Nature 1990;334:245-7.

14. Fuet PF, Collart MA, Grau GE, Kapanci Y, Vassali P. Tumor necrosis factor/cachectin plays a key role in bleomycin-induced pneumopathy fibrosis. J Exp Med 1989; 170:655-63.

15. Goldblum SE, Hennig B, Jay M, Yoneda K, McClain CJ. Tumor necrosis factor $\alpha$-induced pulmonary vascular endothelial injury. Infect Immunol 1989;57:1218-26.

16. Kaibara N, Hotkebuchi T, Takagishi K, Katsuki I. Paradoxical effects of cyclosporine A on collagen arthritis in rats. J Exp Med 1983;158:2007-15.

17. Grau GE, Piguet PF, Vassali P, Lambert PH. Involvement of tumor necrosis factor and other cytokines in immunemediated vascular pathology. Int Arch Allergy Appl Immunol 1989;88:34-9.

18. Frater-Shröder M, Risau W, Hallmann R, Gautschi P, Bohlen P. Tumor necrosis factor alpha, a potent inhibitor of endothelial cell growth in vitro, is angiogenic in vivo. Proc Natl Acad Sci 1987;84:5277-81.

19. Montesano R, Orci L, Vassali P. Human endothelial cell cultures: Phenotypic modulation by leukocyte interleukins. J Cell Physiol 1985;122:424-34. 


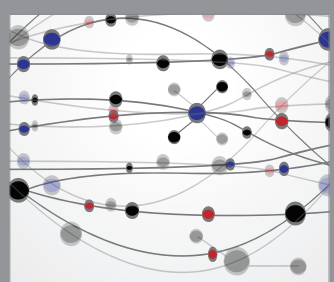

The Scientific World Journal
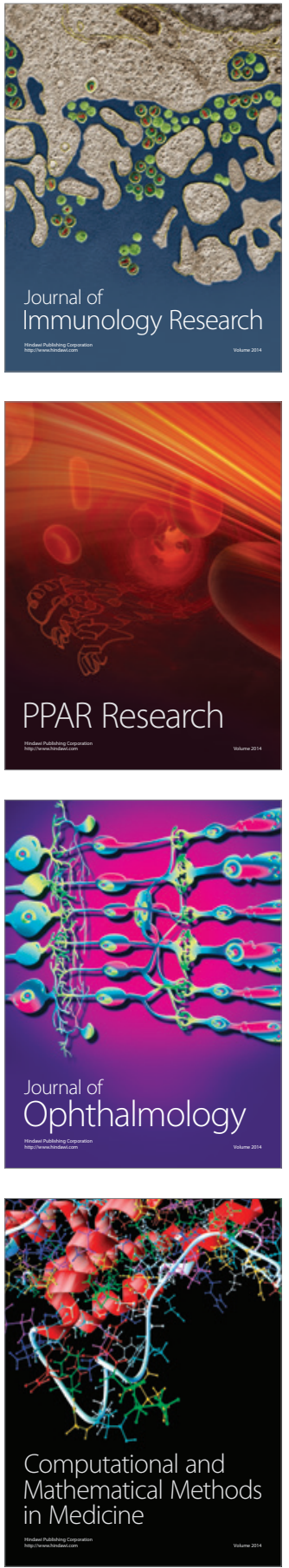

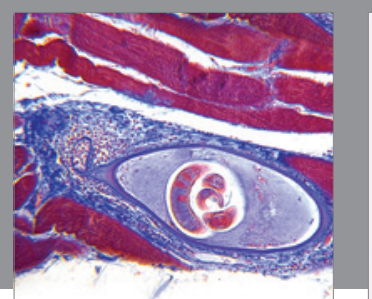

Gastroenterology Research and Practice

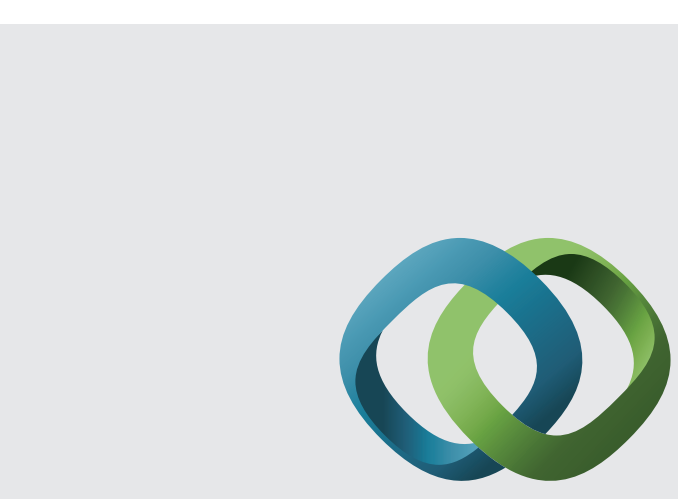

\section{Hindawi}

Submit your manuscripts at

http://www.hindawi.com
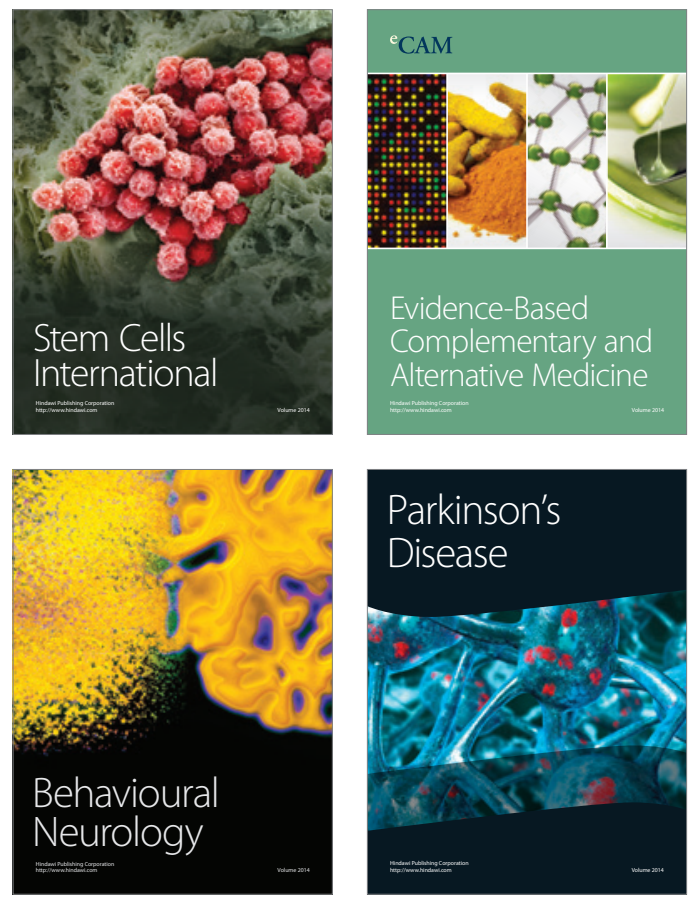
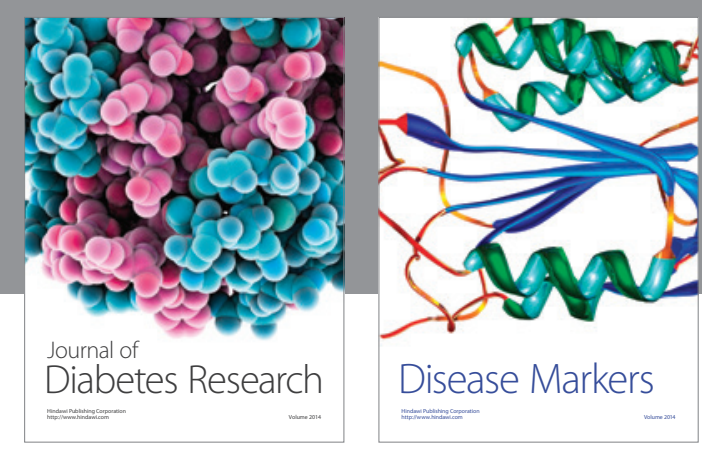

Disease Markers
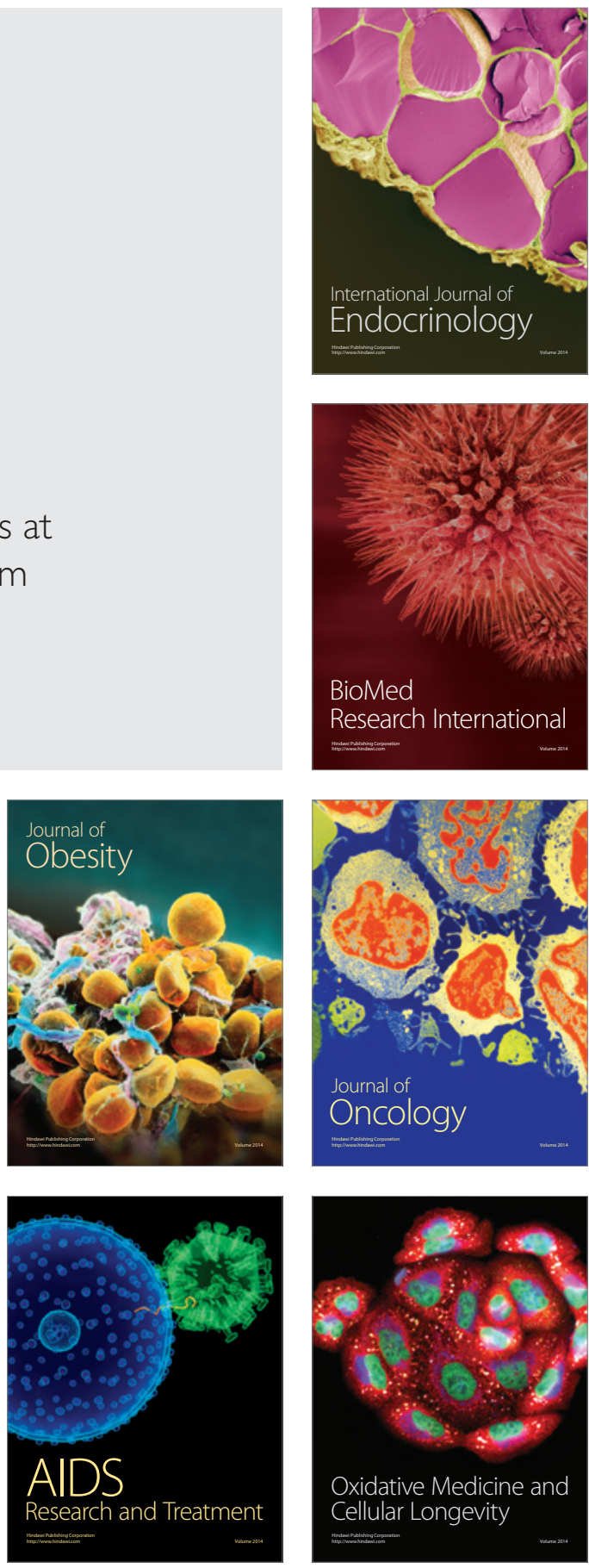